\title{
Effect of aggregate particle shape and granulometry on the workability and mechanical properties of glass reinforced concrete
}

\author{
${\text { Rimvydas Moceikis }{ }^{1} \text {, Asta Kičaité2 }}^{2}$, Gintautas Skripkiūnas ${ }^{3}$ \\ Department of Building Materials and Fire Safety, Vilnius Gediminas Technical University, \\ Vilnius, Lithuania
}

E-mail: 1rimvydas.moceikis@vgtu.lt (corresponding author)

\begin{abstract}
Modern alkali resistant glass fibers (ARG) modified with $17 \% \mathrm{ZrO}_{2}$ are getting more popular as reinforcement of cementitious matrixes. Typical matrix compositions with quartz, Portland cement, $13 \mathrm{~mm}$ length ARG glass fibres and PCE superplasticizer can offer good workability, product quality and highly increased mechanical characteristics. In production of self compacting fibre reinforced premix highly siliceous fine sands with nearly round shape particles are usually preferred. This article investigates influence of particle shape for workability of glass fibre reinforced concrete when alternative fillers- crushed granite and regular sand are used. 12 compositions were made whith different quantities of fillers, changing quartz from $0 \%$ to $50 \%$ with alternative aggregates. Slump tests according to EN 1170-1 were made and showed major impact of particle shape characteristics on mix workability. When quantity of altrernative aggrates was increased, slump of fresh mix decreased and fibre- matrix segregation occurred. New workability factor $\mathrm{W}$ is offered and values calculated, to have numeric representation of workability. Alternative aggregates had no clear influence for flexural strenght, when beams $40 \times 40 \times 160$ were tested. Compressive strength dropped by $25 \%$ when regular sand was used. Typical quartz matrix resulted in lower water absorbtion.
\end{abstract}

Keywords: glass reinforced concrete, glass fibers, workability, particle shape.

\section{Introduction}

Self-compacting glass fibre reinforced concrete (GRC) is becoming popular composite material in the field of various prefabricated decorative concrete elements, from façade claddings to flowerpots. Cementitious quartz matrix is easy to to work with and offers good overall characteristics, from workability to flexural strength.

One of the most common GRC production techniques is premix method, when mortar and precut fibers are mixed together before casting. The quantity of fibers added to the mortar is usually up to $3.5 \%$, in terms of weight, and the length of the fibers is around $12 \mathrm{~mm}$. Longer fibers lead to an excessive reduction of the mix workability therefore are rarely used (Bentur \& Mindess, 1990). Another technique is spray method, when glass fibre strand is chopped and sprayed together with mortar on the mould surface. In this article, only first (premix) method is investigated.

As climate change is getting more and more debated topic, we should not forget other two main challenges, directly associated with building sector- durability of construction materials and remaining resourses for new products for construction market. According to The American Society of Civil Engineers (ASCE) calculations, the average maintenance- free life for a structure built today is approximately only 18.5 years (Abanilla et al., 2006). In Lithuania there is only one quarry of pure quartz sand, perfect for GRC. If consumption will not change, it will last only for 30 years more. Current estimation of available sand- gravel resourses in Lithuania is about 506 milion tons, which means we have enough for 67 more years. For reasons above it is very important to search for alternative GRC matrix fillers instead of quartz sand.

Since 1956 there has been a huge amount of research and development work carried out in the field of glass reinforced cementitious composites and for that reason, GRC can be considered as a trustful building material for various applications when $\mathrm{ZrO}_{2}$ modified glass is used (Vahidi \& Malekabadi, 2011; Rickard, 2015). In 1970's Majumdar A. J. produced alkali resistant glass filaments diameter around $10 \mu \mathrm{m}$ according to single tip furnace method and tested it for reaction with Portland cement in various temperatures from $20^{\circ} \mathrm{C}$ to $65^{\circ} \mathrm{C}$. Durability tests showed that new Zirconia modified glass filament still loses a portion of its pristine strength in alkali environment. Reaction speed is increasing together with temperature, but at ambient temperatures of $20^{\circ} \mathrm{C}$ no significant loss of strength was recorded, and long-term tensile strength of Zirconia modified glass was recorded of around $1200 \mathrm{MPa}$ (Majumdar, West, \& Larner, 1977). Latest scientific investigations offer vide variety of methods to improve durability of glass

(C) 2019 Authors. Published by VGTU Press. This is an open-access article distributed under the terms of the Creative Commons Attribution (http://creativecommons.org/licenses/by/4.0/) License, which permits unrestricted use, distribution, and reproduction in any medium, provided the original author and source are credited. 
fibre reinforced cementitious composites. Some propose to add polymers (Qian, Shen, Mu, \& Li, 2003), others- to incorporate microfillers (Brandt \& Glinicki, 2003; Peled, Jones, \& Shah, 2005; Bartos \& Zhu, 1996), or modify fibre surface with organo-silane and carbon nanotube reinforced Nano clay coatings (Rothe, Gao, Plonka, \& Mader, 2015; Mader \& Plonka, 2004; Gao, Mader, \& Plonka, 2007).

Although there has been (and still is) a tremendous thrust in research programmes to seek for more fibre alternatives, the fibre cement composite producers worldwide have used only a few of the fibre types researched today, one of them being alkali resistant glass fibres (ARG). The reason for this is that choice of a particular fibre type is based on price, availability, compatibility with cement, durability and the reinforcing potential in the cement composite (Akers, 2006). Possible alternative for currently used AR glass fibre in near future might become carbon and basalt when new fibre production techniques will offer significantly lower prices, better durability and cementitious mix workability (High, Seliem, El-Safty, \& Rizkalla, 2015; Xu, Liu, \& Li, 2015).

Some scientific studies show that flexural capacity of self compacting glass reinforced premix is between 9$15 \mathrm{MPa}$, depending on fibre content and additives used. Peter I. D. investigated impact of SCC GRC additives on flexural strength with reference to fibre content, fibre length, water/cement ratio, and workability. CEM I 52,5R was used as binder, polycarboxilic ether-based superplasticizer as water reducing admixture and fine silica sand as filler. Tests showed that flexural strength increased from 8 to $12 \mathrm{MPa}$ when w/c was reduced from 0.42 to 0.32 . Effect of fibre content for flexural strength was more significant than fibre length when fibres used were $13 \mathrm{~mm}$ and $25 \mathrm{~mm}$ by length. $13 \mathrm{~mm}$ fibres resulted in $9 \mathrm{MPa}$ and $25 \mathrm{~mm}-10 \mathrm{MPa}$ (3\% of total mix weight). For $13 \mathrm{~mm}$ fibres, flexural strength increased from $8 \mathrm{MPa}$ to $13 \mathrm{MPa}$ when fibre content was increased from $2 \%$ to $4 \%$ (Peter \& Crocker, 2015). Abe J. Studied self-compacting GRC mixtures with various admixtures (Air-entraining and high-range water-reducing admixture, Separation reduction type water-reducing admixture, Powdered acrylic polymer, Methylcellulose, High performance thickener, Antifoaming agent and micro silica). For all recipes, w/c ratio was 0.30 , fibre content $3.0 \%$ and OPC- quartz sand ratio 1:1. Best flow was achieved with separation reduction type additive and flexural strength of tested plates varied from 11 to $15 \mathrm{MPa}$ (Abe, Takeuchi, Ogata, \& Imai, 2011).

Annother important factor, influencing mechanical characteristics of concrete is granulometric composition. There are no scientific research addressing this issue for glass fibre reinforced concrete. In general theory, the packing density of a granular mix is defined as the solid volume $\Phi$ in a unit total volume. Alternatively, the compaction may be described by the porosity $(\pi=1-\Phi)$. In the past, the design strategy has generally been to proportion the different grains to obtain a grading curve close to an 'ideal' grading curve, which is supposed to produce the maximum packing density. The packing density of a polydisperse grain mixture depends on three main parameters: the size of the grains considered (described by the grading curves), the shape of the grains and the method of processing the packing (de Lerrard, 1999).

\section{Materials and test methods}

12 GRC compositions were tested for workability and flexural toughness. 3 types of aggregates with different particle size and shape were used to identify their influence for mix workability. Other components were kept constant. Manufactured in Lithuania Portland cement CEM I 52,5R was used as a binder. Fine granite, quartz and regular sand were chosen as aggregates. Polycarboxilic ether- based superplasticizer was chosen as a water reducing agent and alkali resistant (AR) glass fibers for matrix reinforcement.

Chemical composition of CEM I 52,5R is given in Table 1. Its specific (blaine) surface was $5100 \mathrm{~cm}^{2} / \mathrm{g}$, particle density $3.13 \mathrm{~g} / \mathrm{cm}^{3}$ and mean diameter of particles- $9.31 \mu \mathrm{m}$. Particle size distribution is given in Figure 1 .

Table 1. Chemical composition of cement

\begin{tabular}{|c|c|c|c|c|c|c|c|c|c|c|}
\hline & $\mathrm{CaO}$ & $\mathrm{SiO}_{2}$ & $\mathrm{Al}_{2} \mathrm{O}_{3}$ & $\mathrm{Fe}_{2} \mathrm{O}_{3}$ & $\mathrm{MgO}$ & $\mathrm{SO}_{3}$ & $\mathrm{~K}_{2} \mathrm{O}$ & $\mathrm{Na}_{2} \mathrm{O}$ & $\mathrm{Na}_{2} \mathrm{O}_{\text {eq }}$ & $\mathrm{Cr}$ \\
\hline CEM I 52,5R & 63.99 & 19.84 & 5.24 & 2.99 & 1.55 & 3.05 & 0.78 & 0.25 & 0.76 & 0.062 \\
\hline
\end{tabular}

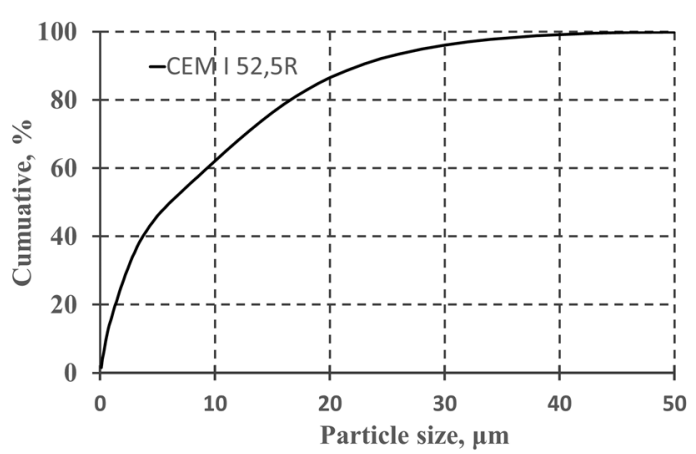

Figure 1. Particle size distribution of Portland cement CEM I 52,5R 
Properties of aggregates are given in Table 2, granulometrical compositions of all fillers are given in Figure 2. Quartz has narrow particle distribution with $90 \%$ of particles between $0.125-0.5 \mathrm{~mm}$. Granite and regular sand has almost identical granulometries with even distribution between $0.125-2 \mathrm{~mm}$.

Table 2. Main Properties of aggregates

\begin{tabular}{|l|c|c|c|}
\hline \multicolumn{1}{|c|}{ Properties } & Quartz & Granite & Regular Sand \\
\hline $\mathrm{d}_{\max }, \mathrm{mm}$ & 0.5 & 2 & 2 \\
\hline Bulk density, $\mathrm{kg} / \mathrm{m}^{3}$ & 1640 & 1530 & 1450 \\
\hline Specific gravity, $\mathrm{kg} / \mathrm{m}^{3}$ & 2650 & 2800 & 2600 \\
\hline Water absorption, $\%$ & $<0.5$ & $<0.6$ & $<0.5$ \\
\hline
\end{tabular}

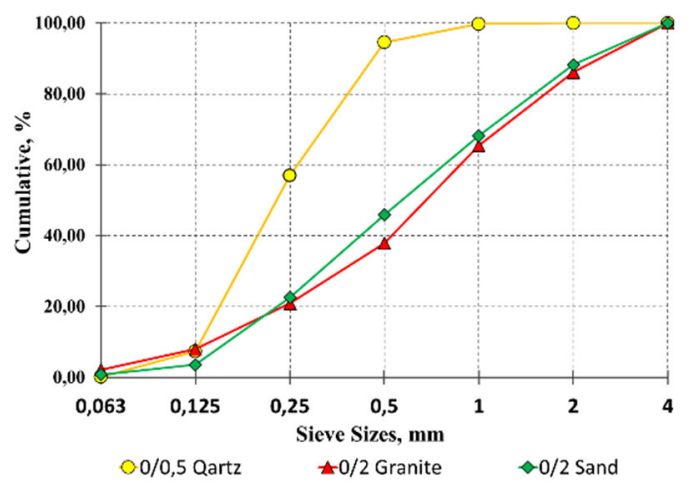

Figure 2. Particle size distribution of used aggregates- quartz, granite and regular sand

Each fibre is a bundle of 200 filaments with diameter of $18 \mu \mathrm{m}$. Filaments are layered on each other in series, giving a flat rectangular shape of the fibres, with total width about $1.5 \mathrm{~mm}$. Length of fibres was $13 \mathrm{~mm}$, tensile strength $1400 \mathrm{MPa}$, modulus of elasticity $74 \mathrm{GPa}$ and melting temperature, common for glass- $1100{ }^{\circ} \mathrm{C}$.

Mix compositions were divided into two groups- $\mathrm{G}$ and $\mathrm{S}$ and are given in Table 3. Quantities of cement and fillers are given in proportions, superplasticizer is in percentage from mass of cement and glass fibres in percentage from the mass of whole matrix.

High shear mixer with up to 800 RPM was used for batching. Water, cement, plasticizer and aggregates were blended for 120 s with maximum revolutions ( $800 \mathrm{RPM})$. After that, glass fibres were added and dispersed into the cementitious matrix with 300-400 RPM for 60 seconds.

Table 3. Relative compositions

\begin{tabular}{|l|c|c|c|c|c|c|c|c|c|c|c|c|}
\hline Materials & G0 & G1 & G2 & G3 & G4 & G5 & S0 & S1 & S2 & S3 & S4 & S5 \\
\hline CEM I 52,5R & 1 & 1 & 1 & 1 & 1 & 1 & 1 & 1 & 1 & 1 & 1 & 1 \\
\hline Superplasticizer & $1.1 \%$ & $1.1 \%$ & $1.1 \%$ & $1.1 \%$ & $1.1 \%$ & $1.1 \%$ & $1.1 \%$ & $1.1 \%$ & $1.1 \%$ & $1.1 \%$ & $1.1 \%$ & $1.1 \%$ \\
\hline W/C & 0,36 & 0,36 & 0,36 & 0,36 & 0,36 & 0,36 & 0,36 & 0,36 & 0,36 & 0,36 & 0,36 & 0,36 \\
\hline Quartz 0/1.25 & 1 & 0.9 & 0.8 & 0.7 & 0.6 & 0.5 & 0 & 0.9 & 0.8 & 0.7 & 0.6 & 0.5 \\
\hline Granite 0/2 & 0 & 0.1 & 0.2 & 0.3 & 0.4 & 0.5 & 0 & 0 & 0 & 0 & 0 & 0 \\
\hline Sand 0/2 & 0 & 0 & 0 & 0 & 0 & 0 & 1 & 0.1 & 0.2 & 0.3 & 0.4 & 0.5 \\
\hline Glass fibre & $2.9 \%$ & $2.9 \%$ & $2.9 \%$ & $2.9 \%$ & $2.9 \%$ & $2.9 \%$ & $2.9 \%$ & $2.9 \%$ & $2.9 \%$ & $2.9 \%$ & $2.9 \%$ & $2.9 \%$ \\
\hline
\end{tabular}

Beams $40 \times 40 \times 160$ were produced to test flexural and compressive strength after 28 days according to EN 196-1. Workability of fresh concrete was tested according EN 1170-1, which is based on a slump test with cylinder Ø65, $h=55 \mathrm{~mm}$.

\section{Results and discussion}

\section{Concrete densities}

Glass fiber reinforced concrete is a polydisperse grain mixture, consisting of two dominant particle size distribution intervals with close to equal proportion: $\mathrm{D} 1<20 \mu \mathrm{m}$ (cement) and D2 $=[125 \ldots 2000 \mu \mathrm{m}]$ (filler). Glass fibre 
inclusions are occupying $<5 \%$ of total mix volume. As particles of the filler are relitevely close to each other, any variations of filler granulometry or particle shape could have influence on concrete workability (Figure 3). Fresh mix densities for $\mathrm{G}$ and $\mathrm{S}$ compositions are ranging from $2196 \mathrm{~kg} / \mathrm{m}^{3}$ to $2248 \mathrm{~kg} / \mathrm{m}^{3}$ and are given in Figure 4. Hardened concrete densities were ranging from $2069 \mathrm{~kg} / \mathrm{m}^{3}$ to $2133 \mathrm{~kg} / \mathrm{m}^{3}$.

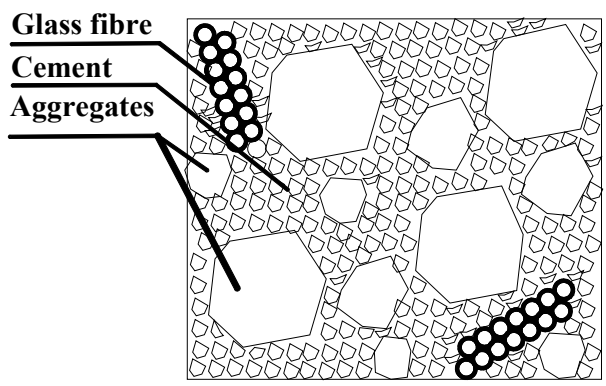

Figure 3. Particle size distribution of typical GRC mix

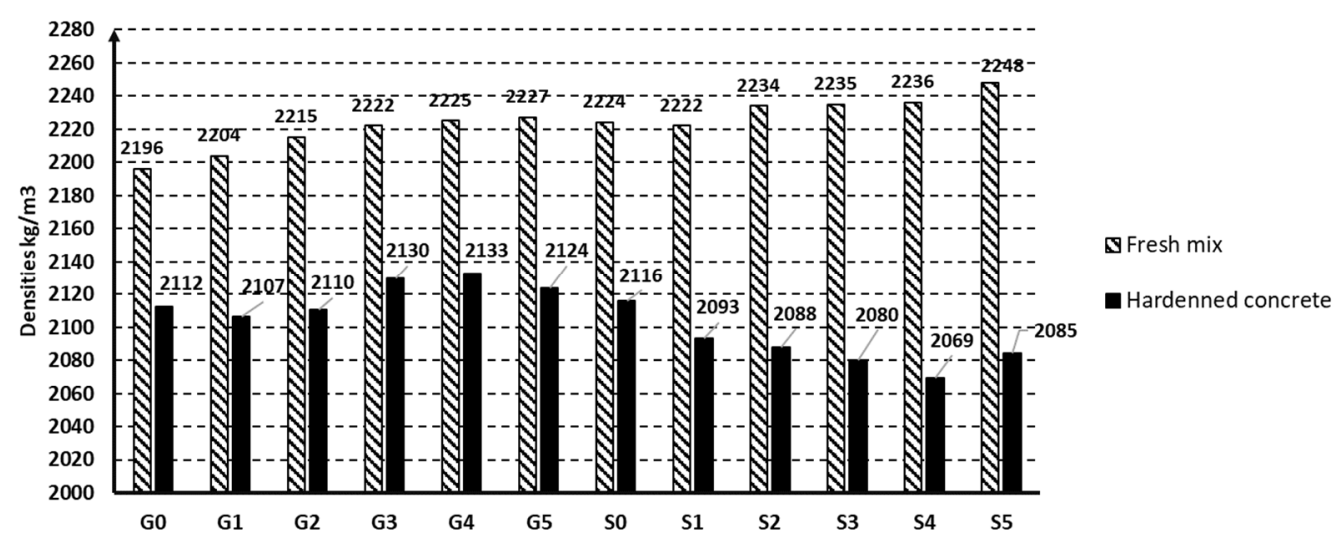

Figure 4. Fresh mix and hardened concrete densities

\section{Workability}

It is relatively easy to make self-compacting glass fibre reinforced premix when quartz filler is used (G0 mix). Other fillers, such as crushed granite or regular fine sand results to water bleeding and segregation. In order to investigate this effect, several mix compositions were prepared by changing quartz matrix with $10 \%, 20 \%, 30 \%, 40 \%, 50 \%$ and $100 \%$ alternative fillers (granite or regular sand). Fibre- matrix segregation was noticeable in all modified compositions and for this reason, several parameters were introduced to typical GRC workability test according to slump method EN-1170-1 (Figure 5).

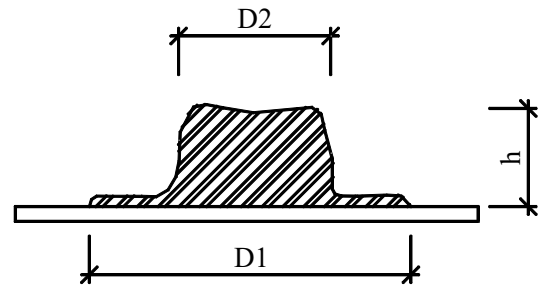

Figure 5. Additional GRC workability parameters to EN1170-1

According to scheme given in Figure 5, we can state that workability index $W$ is directly proportional to $D 1$ and $D 2$, but indirectly to $h$. This can be written as:

$$
W=(D 1 \cdot D 2) / h, \mathrm{~cm} .
$$

If we assume, that for typical self-compacting GRC $D 1=D 2=22 \mathrm{~cm}$, and $h=1.3 \mathrm{~cm}$, then we get $W=372 \mathrm{~cm}$. Workability indexes for all compositions are given in Table 4 and workability parameters in Figure 6 . As we can see, added alternative fillers to the quartz matrix decreases mix workability. Particle size distributions of crushed granite and regular sand are very similar, even though there is a clear difference in workability (Figure 7). 
Moceikis, R.; Kičaitè, A.; Skripkiūnas, G. 2019. Effect of aggregate particle shape and granulometry on the workability and mechanical properties of glass reinforced concrete
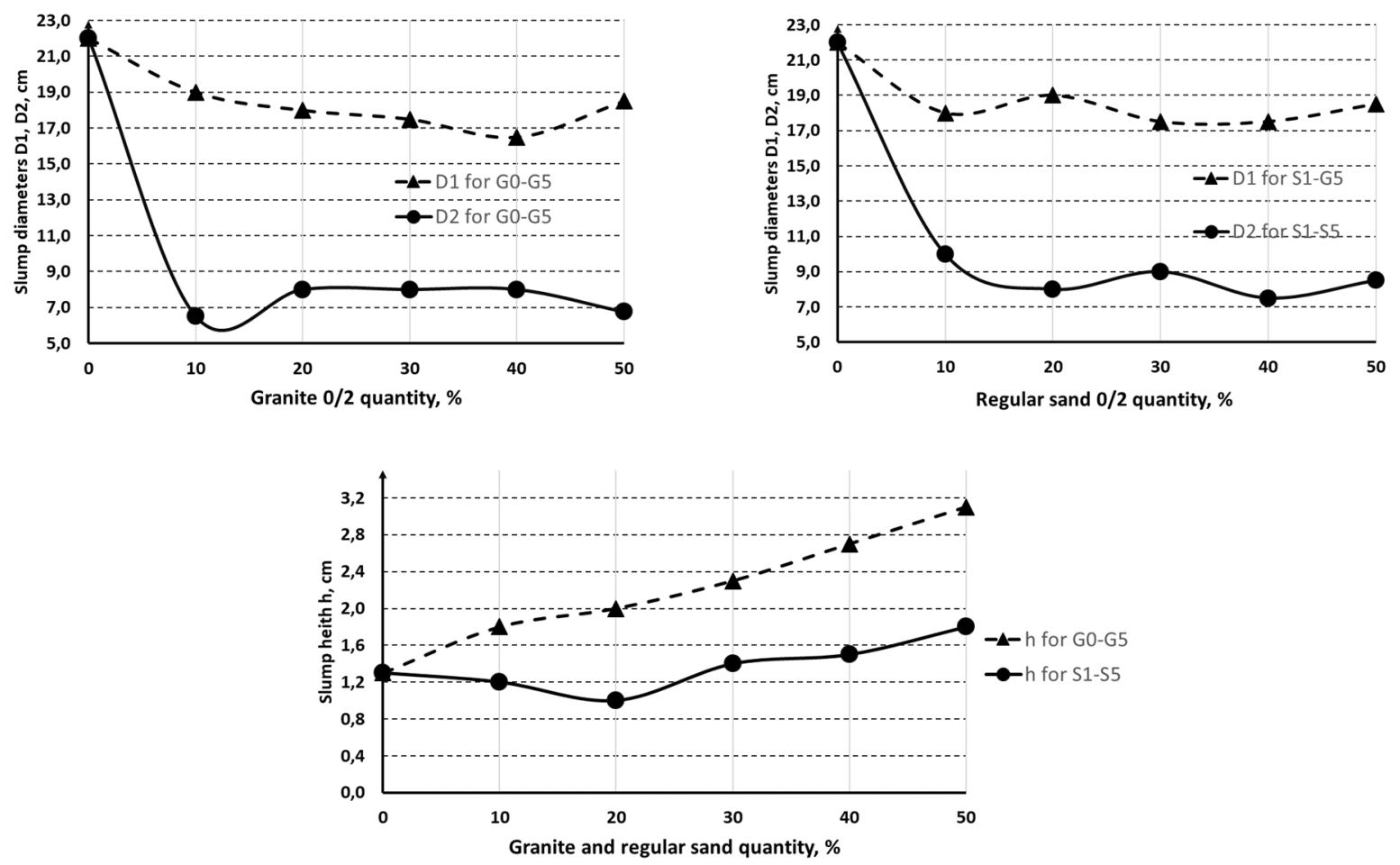

Figure 6 . Workability parameters $D 1, D 2$ and h for compositions with granite and regular sand

Table 4. Workability indexes

\begin{tabular}{|c|c|c|c|c|c|c|c|c|c|c|c|c|}
\hline & G0 & G1 & G2 & G3 & G4 & G5 & S0 & S1 & S2 & S3 & S4 & S5 \\
\hline W & 372 & 69 & 72 & 61 & 49 & 40 & 45 & 150 & 152 & 113 & 88 & 87 \\
\hline
\end{tabular}

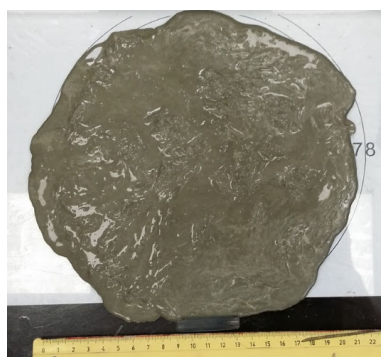

a)

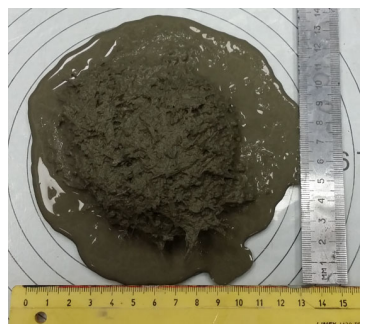

c)

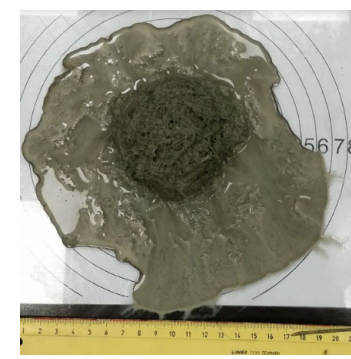

b)

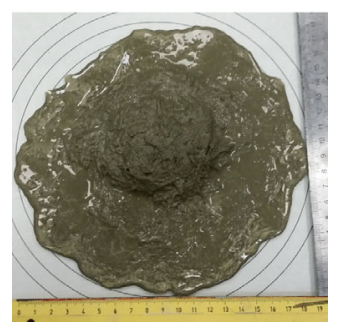

d)

Figure 7. Workability test: a) composition G0 (quartz matrix); b) G5 (50\% qyartz replaced by granite);

c) S0 (typical sand matrix); d) S5 (50\% of quartz replaced by sand)

This difference can be explained by particle shape. Quartz sand particles have close to round shape, resulting into good flow of the mix, because there is little interaction between aggregate itself and aggregate to fibres. Granite has particles with sharp edges, which creates crowding effect between glass fibres and aggregate and results in fibre- matrix segregation. Regular sand has multangular particles with less sharp edges than granite, which result in better workability. These ideas are represented graphically in Figure 8. 


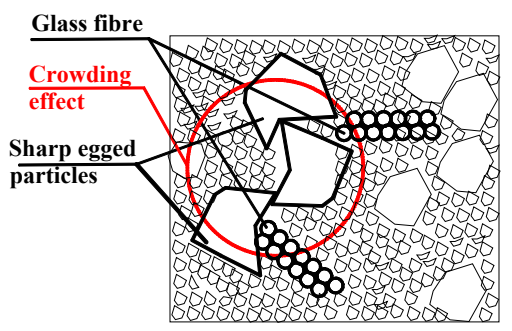

Figure 8. Graphical representation of matrix segregation in compositions with sharp shape particles (crowding effect)

\section{Compressive strength}

Compressive tests showed that highest packing density and compressive strength of $82.97 \mathrm{MPa}$ is achieved with quartz matrix (G0). Changing 50\% of quartz with granite reduced compressive strength by $17 \%$ down to $68.59 \mathrm{MPa}$. Adding even small amounts (10\%) of regular sand to quartz matrix reduces compressive strength significantly, to $63-$ $65 \mathrm{MPa}$ (Figure 9).

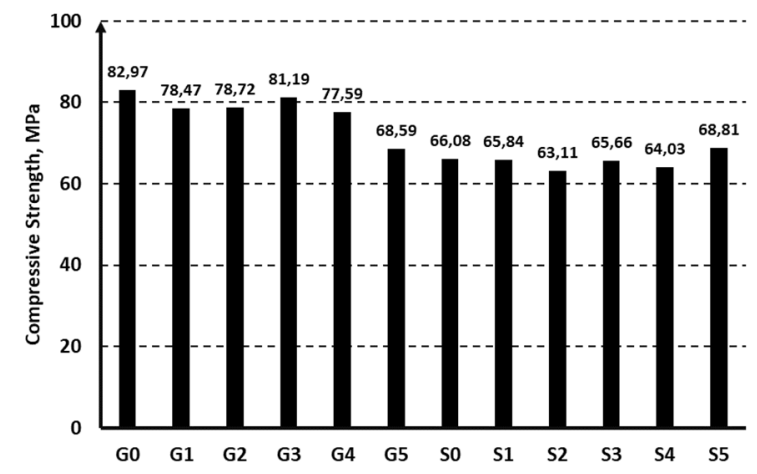

Figure 9. Compressive strength after 28 days

\section{Flexural strength}

Prisms $40 \times 40 \times 160$ were tested for flexural strength and results varied from 11.34 MPa to 13.4 MPa (Figure 10). Pure quartz gives good flexural capacity $(>13 \mathrm{MPa})$ and modification of matrix with granite or regular sand did not result in increased flexural strength of GRC composite.

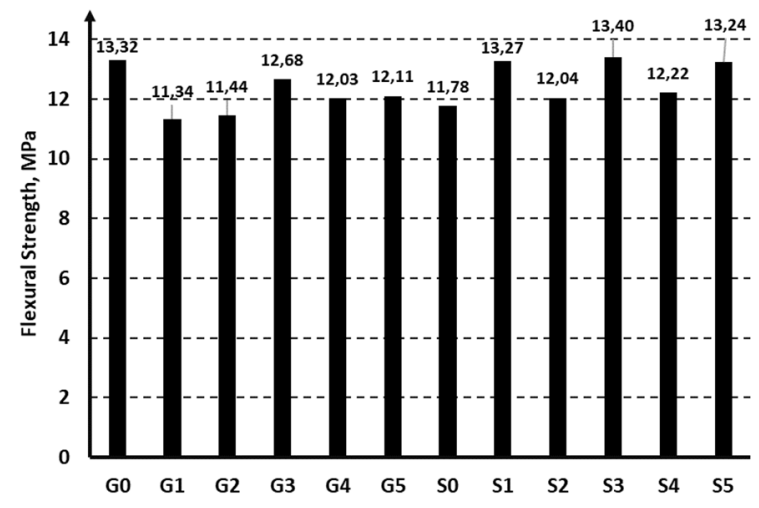

Figure 10. Flexural strength after 28 days

\section{Water Absorption}

Due to high content of Portland cement, GRC has higher water absorption, compared to regular concrete. Average values of water absorption after $60 \mathrm{~min}$ immersion was $9 \%$ and $11.4 \%$ after $48 \mathrm{~h}$ immersion for prisms $40 \times 40 \times 160$. (Figure 11). Lowest water absorption was reached with quartz matrix-10.8\% after $48 \mathrm{~h}$ and $8 \%$ after 60 min. 

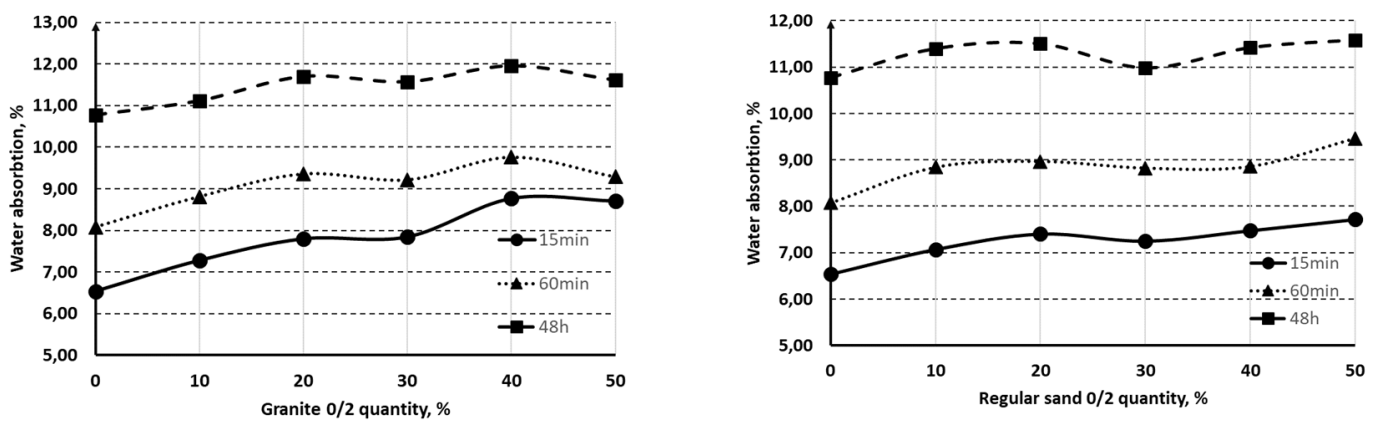

Figure 11. Water absorption of prisms $40 \times 40 \times 160$ after $15 \mathrm{~min}, 60 \mathrm{~min}$ and $48 \mathrm{~h}$

\section{Conclusions}

Workability and mechanical characteristics of glass fibre reinforced concrete premix with different aggregates was investigated. Alternative fillers- chrushed granite and regular sand were incorporated into typical quartz matrix. When alternative fillers are added, fiber- matrix segregation occurs which can be explained by crowding effect between glass fibres and multangular particles with sharp edges. New concept of workability factor $W$ was introduced in this article to supplement standard test method EN1170-1. Changing up to 50\% of typical GRC quartz matrix with $0 / 2$ crushed granite increases hardened concrete density by up to $50 \mathrm{~kg} / \mathrm{m}^{3}$ and decreases by $21 \mathrm{~kg} / \mathrm{m}^{3}$, when regular sand is used. Compressive strength with typical quartz matrix is about $83 \mathrm{MPa}$ and it decreases by $17 \%$ down to $63 \mathrm{MPa}$, when granite or regular sand is incorporated. Pure quartz gives good flexural capacity (13 $\mathrm{MPa})$ and modification of matrix with granite or regular sand did not result in increased flexural strength of GRC composite. Lowest water absorption was reached with quartz matrix- $10.8 \%$ after $48 \mathrm{~h}$ and $8 \%$ after $60 \mathrm{~min}$. Water absorption is increasing when alternative fillers (granite and regular sand) are used instead of fine quartz.

\section{References}

Abanilla, M. A., Azhari, F., Banthia, N., Benmokrane, B., Bisby, L. A., Boulfiza, M., Christensen, P., ..., \& Zhang, J. (2006). Durability of fibre reinforcef polymers in Civil infrastructure (Durability Monograph). ISIS Canada reseach network.

Abe, J., Takeuchi, Y., Ogata, Y., \& Imai, K. (2011). Development of self-compacting premix GRC. GRCA Symposium 2011. Istanbul.

Akers, S. (2006). Cracking in fibre cement products. In $10^{\text {th }}$ International Conference Inorganic - Bonded Fiber Composites, 1518 November 2006. Sao Paulo, Brasil. 59 p.

Bartos, J. M., \& Zhu, W. (1996). Effect of microsilica and acrylic polymer treatment on the ageing of GRC. Cement and Concrete Composites, 18(1), 31-39. https://doi.org/10.1016/0958-9465(95)00041-0

Bentur, A., \& Mindess, S. (1990). Fiber reinforced cementitious composites. New York: Taylor \& Francis. 595 p.

Brandt, A. M., \& Glinicki, M. A. (2003). Effects of pozzolanic additives on long-term flexural toughness of HPGRC. Fourth international workshop on high performance fiber reinforced cement composites. University of Michigan and the University of Stuttgard.

de Lerrard, F. (1999). Concrete mixture proportioning: A scientific approach (1 ${ }^{\text {st }}$ ed.). London. $448 \mathrm{p}$.

Gao, S. L., Mader, E., \& Plonka, R. (2007). Nanocomposite coatings for healing surface defects of glass fibers and improving interfacial adhesion. Composites Science and Technology, 68(14), 2892-2901. https://doi.org/10.1016/j.compscitech.2007.10.009

High, C., Seliem, H. M., El-Safty, A., \& Rizkalla, S. H. (2015). Use of basalt fibers for concrete structures. Construction and Building Materials, 96, 37-46. https://doi.org/10.1016/j.conbuildmat.2015.07.138

Mader, E., Plonka, R., Schiekel, M., \& Hempel, R. (2004). Coatings on alkali-resistant glass fibres for the improvement of concrete. Journal of Industrial Textiles, 33(3), 191-207. https://doi.org/10.1177/1528083704039833

Majumdar, A. J., West, J. M., \& Larner, L. J. (1977). Properties of glass fibres in cement environment. Journal of Materials Science, 12(5), 927-936. https://doi.org/10.1007/BF00540975

Peled, A., Jones, J., \& Shah, S. P. (2005). Effect of matrix modification on durability of glass fiber reinforced cement composites. Materials and Structures, 38(2), 163-171. https://doi.org/10.1007/BF02479341

Peter, I. D., \& Crocker, I. (2015). Further Investigations into Premix GRC. GRCA Symposium 2015. Dubai.

Qian, X., Shen, B., Mu, B., \& Li, Z (2003). Enhancement of aging resistance of glass fiber reinforced cement. Materials and Structures, 36, 323-329.

Rickard, C. (2015). GRC developments in Australia. In $17^{\text {th }}$ International Congress of the GRCA, 19-21 April 2015. Dubai.

Rothe, C., Gao, L. S., Plonka, R., \& Mader, E. (2015). Nano surface structuring of alkali- resistant glass fibres for multifunctional effects. In $1^{\text {st }}$ International Conference Textile Reinforced Concrete. Leibniz Institute of Polymer Research Dresden, Germany.

Vahidi, E., \& Malekabadi, M. (2011). GRC and sustainable building design. In $17^{\text {th }}$ International Congress of the GRCA, 19-21 April 2011. Istambul.

Xu, S., Liu, J., \& Li, Q. (2015). Mechanical properties and microstructure of multi-walled carbon nanotube-reinforced cement paste. Construction and Building Materials, 76, 16-23. https://doi.org/10.1016/j.conbuildmat.2014.11.049 